Correction: Does tranexamic acid lead to changes in MRI

measures of brain tissue health in patients with spontaneous

intracerebral haemorrhage? Protocol for a MRI substudy

nested within the double-blind randomised controlled TICH-

\title{
2 trial
}

Dineen RA, Pszczolkowski S, Flaherty K, et al. Does tranexamic acid lead to changes in MRI measures of brain tissue health in patients with spontaneous intracerebral haemorrhage? Protocol for a MRI substudy nested within the double-blind randomised controlled TICH-2 trial. BMJOpen 2018;8:e19930. doi: 10.1136/bmjopen-2017-019930

On the secondary outcomes subsection (page 3) it reads:

'Only DWIHL that are confirmed of low diffusion on the derived apparent diffusion coefficient maps and spatially remote from the index ICH $(<20 \mathrm{~mm})$ will be included as previously.'

It should read:

Only DWIHL that are confirmed of low diffusion on the derived apparent diffusion coefficient maps and spatially remote from the index ICH $(>\mathbf{2 0} \mathbf{~ m m})$ will be included as previously.'

Open Access This is an Open Access article distributed in accordance with the terms of the Creative Commons Attribution (CC BY 4.0) license, which permits others to distribute, remix, adapt and build upon this work, for commercial use, provided the original work is properly cited. See: http://creativecommons.org/licenses/by/4.0/

C Article author(s) (or their employer(s) unless otherwise stated in the text of the article) 2018. All rights reserved. No commercial use is permitted unless otherwise expressly granted.

BMJ Open 2018;8:e019930corr1. doi:10.1136/bmjopen-2017-019930corr1

A) Check for updates 